\title{
Puritanism vs. Syncretism: An Islamic Cultural Collision in the Rural Farmer Community in Trucuk, Indonesia
}

\author{
Sutiyono Sutiyono ${ }^{1}$, Syafiq M. Mughni ${ }^{2} \&$ Hotman M. Siahaan ${ }^{3}$ \\ ${ }^{1}$ Faculty of Languages and Arts, Yogyakarta State University, Indonesia \\ ${ }^{2}$ Faculty of Adab, Islamic State Institite of Sunan Ampel, Indonesia \\ ${ }^{3}$ Faculty of Social and Politic, Airlangga University, Indonesia \\ Correspondence: Sutiyono Sutiyono, Dance Education Department, Faculty of Languages and Arts, Yogyakarta \\ State University, Jl. Colombo No. 1 Yogyakarta, Indonesia. Tel: 02-74-58-6168. E-mail: \\ sutiyono_63@yahoo.com
}

Received: June 14, 2015 Accepted: November 5, 2015 Online Published: November 27, 2015

doi:10.5539/ass.v11n28p200 URL: http://dx.doi.org/10.5539/ass.v11n28p200

\begin{abstract}
This writing presents a view on the change in the rural farmer community in Trucuk from being abangan-syncretic to being santri-puritan. After becoming puritan, it is radical in style. The radical style becomes a social phenomenon causing the occurrence of cultural collision of puritan Islamic cultural values versus syncretic ones in the region of the rural farmer community in Trucuk. This research is done in a rural area in Trucuk district, Klaten regency, Central Java provence, Indones. The major of collecting data methods are participant observer, deep interview, and study documentation. This research uses ethnography approach. The results show that the change in farmer's society in a rural are from syncretism to Puritanism influenced by education rationalization and religion up gradation. After being Puritanism, the characteristics changes to plural those are racialism and moderate. Particularly for radicalism that is to be a social phenomenon caused by kept of syncretism. In addition the other factor of Muhammadiyah movement to do the radicalism is the background of Klaten as an imbalance and seethed place since period Hinduism. The radicalism is done as s effort to return to Al-Qur'an emerge the perception and religious behavior that is believed as the truest thing. This perception and behavior emerge the feeling that Puritanism Islamic is the truest and perfect religion, and it can save them, and considered other religion is the polluted or mixed with other unsure, especially syncretism. So, they think that syncretism is misleading, through radicalism, Puritanism try to reduce the practice of syncretism.
\end{abstract}

Keywords: puritanism, syncretism, radicalism, cultural collision

\section{Introduction}

The research concerned here started from the point of Geertz' conception mentioning that religion is considered part of the cultural system. He views religion as pattern for behaviour, in the sense that religious values become alive in human individuals and become visible in daily life. Thus, religion is a guide used as framework for the interpretation of human actions (Geertz, 1973).

A number of farmer community members that used to be abangan (Note 1) in their social orientation, as written by Geertz in The Religion of Java in the 1950s, have now turned santri (Note 2), as seen in the rural community in Trucuk (Note 3). The social change of the farmer community members from being abangan becoming santri indicates a process of change occurring for a sufficiently long time, i.e., around half a century. When the movement of Islamic puritanism pioneered by Muhammadiyah (Note 4) entered the rural region of Mojokuto, it did not get enough sympathy from the farmer community members. Their participation in the puritan movement was quite little. In Geertz' rough calculation, not more than forty people from the community participated. At present, the number of people from the farmer community participating in the puritan movement in Trucuk has risen to roughly 11,000 .

The process of change in the farmer community members becoming santri, which has occurred for a sufficiently long time, could surely be viewed from the point of various influencing factors. In other words, there have been factors influencing the farmer community members into accepting the Islamic puritanism movement. The Islamic puritanism movement, which has a radical style, has been quite phenomenal; though radical in style, the 
Islamic puritanism movement in Trucuk has been accepted by rural farmer community members. It is certainly not in line with Geertz (1960), who states that it is difficult for a radically-spread puritan movement to win the participation of rural communities and of farmers in particular.

In addition, the radical style of the Islamic puritanism movement differs from those in Kotagede (Nakamura, 1983), Banyuwangi (Beatty, 2001), and Lamongan (Chamim, 2003). In this relation, it is seen that those involved in the Islamic puritanism movement used to be of the same kind of community, namely, syncretic-abangan-farmer community. In the process of change from being a syncretic farmer community into being a puritan one, no social conflict has occurred because at first the puritan movement in the three last mentioned places was not radically spread. What is to view is then why the one in Trucuk has differed from the ones in Kotagede, Banyuwangi, and Lamongan, since, after all, they are the same in role as puritan movement and in origin as farmer community.

This writing attempts to interpret different value levels, i.e., both that of farmer community members still syncretic-abangan in orientation and that of those already changed into puritan ones, including those changed further into ones radical-puritan in a style colored with cultural collision resulting from difference in pattern of action and interpretation on the religious or ideological devices used by the actors concerned to confront their social environment. The difference in pattern of action and interpretation is reflected in the social and religious life of the Islamic community in the rural region of Trucuk, where that community is divided into two social groups, namely, one in support of puritan culture and another in support of syncretic culture. They are the same in making the claim of being Islam believers but differ in pattern of action and interpretation in their social and religious life or, in other words, they have different cultural systems.

\section{Literature Review}

\subsection{Syncretism}

The cultural system which the abangan-syncretic farmer group bears is one which depicts a mixture between Islamic culture and local culture and the mixture is referred to at least here as syncretism. The depiction of syncretism is also said to be of a syncretic Islamic culture, that is, the depiction of a religious genre which has gone far from its pure nature. However, this group is highly permissive towards local cultural elements. An example of that instance is what is called slametan, which is a traditional ceremony presenting Islamic prayers as its soul and local devices in the form of traditional food as its vessel in syncretic Islamic culture.

Both the Islamic prayers and the local devices are not so restricted by certain rules. In slametan, when the words alamin, alaikum, bismillah, and Muhammad in the Islamic prayers are pronounced ngalamin, ngalaikum, semilah, and Mukamad, for example, it is allowed or valid. The person acting as prayer leader, usually called modin, need not be a master of Islamic religious knowledge or science; the important thing is that the person could pray. Similarly, the local devices like cooked rice, various dishes, and fruits need not be complete; they could be replaced with cooked rice and fried chicken for the reason that it is more practical that way. In fact, lately the local devices usually presented in the form of cooked or ready-to-eat food have been replaced with raw food materials like uncooked rice, sugar, raw eggs, dry tea leaves, and dry instant noodles. Nevertheless, the changes have caused no social conflict for, obviously, slametan puts more importance in social harmony.

This aspect of harmony is what makes most rural community members feel close to the syncretic Islamic social group. It is also what makes them decide to retain traditional ceremonies or rituals like slametan, faith in walis (pioneer Islamic preachers in Java) or important syncretic Islamic figures, and the custom of making pilgrimages so highly criticized by the puritans (Geertz, 1960; dan Feillard, 1999). Geertz regards abangan as syncretist muslims and santri as purist muslims. He divides santri into two types, namely, modern santri of modernist Islam, referring to Muhammadiyah members (regarded as reformist muslims) and old-fashioned santri (or santri kolot) of traditional Islam, referring to NU members (regarded as traditionalist muslims). Slametan, tahlilan, yasinan, and ziarah are practiced by abangan people and NU members. In fact, the non-puritan Islamic social group has become a backing or supporter of the syncretic Islamic cultural system.

The position of syncretic Islamic culture as local culture is also viewed as that of an "object" under pressure from the puritan Islamic cultural system. In the process, syncretic Islamic culture in its form as local culture has received Islamic values. However, substantially the syncretic Islamic cultural system has also countered with certain resistance related in particular to the system of ideology and social institution in the form of Javanese culture. Therefore, in rural areas at present there has been a struggle between the puritan Islamic movement and the syncretic one. 


\subsection{Puritanism}

The cultural system that the puritan farmer group bears is one that yearns for the return of the pure form of Islamic religious life guided by the cultural system originating in the holy texts and that form of religious life is called puritanism. This puritan group makes efforts to intensify the unearthing of Islamic law. Islamic law is a codification of a set of behavioral norms taken from Al-Qur'an and Hadist Nabi Muhammad. Islamic law is applied in the form of rituals and behaviors which could be called kesalehan normative ('normative piety'). Kesalehan normatif is defined by Woodward as a set of behaviors already described by Allah through His messenger, Muhammad, for use by all followers of Islam.

In the field of preaching and spreading Islam, it is decided that the banning of religious activities considered forms of deviation in faith be intensified by means of upholding the movement of rejecting syncretic Islamic cultural values. The puritanists invite anyone concerned to improve the degree of being Islamic in their society so that it becomes truly Islamic. Such Islamic puritanism movement has been shown by the Islamic farmer group fighting for Islamic law on the way to the process of reproducing the original Islamic culture. Therefore, the movement appears to be more doctrinaire in nature and resembles the Islamic movement in its place of origin, Arabia. The cultural style and reproduction process of the Islamic puritanism movement are quite textual-formal like the Islamic values contained in the Hanbali mazhab ('school of thought') and the Wahabi movement. As for any relation between the Islamic puritanism movement and the aforesaid mazhab and movement, puritan Islam adopts the idea of the pure soul or essence of Islam built by Imam Ibnu Hanbal and continued by his followers, one of whom is Ibnu Taimiyah in his orientation called syariat politics (or as-siyasah as-syariyyah), which commands enforcement of syariat Islam (i.e., Islamic law) and just and pious governance in the life of Islamic society (Taimiyah, 1996).

Culturally, the puritan Islamic cultural system is more expansive in nature, in the sense that its existence is regarded as a great tradition which deeply moves, penetrates, and presses into a new region that has long lived with a syncretic cultural system. Thus, the syncretic cultural system is positioned as little tradition considered in need of adjusting itself to the puritan Islamic cultural system. In fact, in their social-action behavior, puritan Islamic society members make efforts to deconstruct the life order of syncretic Islamic society which contains TBC referring to takhayul, bid'ah, and khurofat. In history, global puritan Islamic movements were shown by Ibnu Taimiyah and Muhammad bin Abdul Wahhab. These movements were romantically obsessed with the idea of Islamic unity based on uniformity in the theological concept of purity in worshipping God. Therefore, in the cultural system the puritan Islamic social group endeavors to push far away syncretic tradition which contains the aforesaid TBC, namely, takhayul, bid'ah, and khurofat.

\subsection{Indications of Cultural Collision}

Exploratory research was made in sites said to be keramat (i.e., having a supernatural element) and places of traditional activity which are highly prominent as centers of syncretic culture in the region of Klaten and simultaneously as centers of pariwisata ziarah (i.e., pilgrimage tourism). Such places are, among others, three famous graves, namely, those of, respectively, Sunan Pandanaran in Bayat, Ki Ageng Gribig in Jatinom, and R. Ng. Ronggowarsito in Trucuk. Such keramat sites have been opposed by the Islamic puritanism movement due to their extremely great escalation in many things. Since around the beginning of the last decade, there have been frequent occurrences of cultural clash in the region of Trucuk, colored with a tug of war between Islamic society members supporting puritanism and those supporting syncretism; because it has always been initiated with a confirmation of each own cultural identity, the result has been collisions between syncretic Islamic culture and puritan Islamic culture.

Cultural conflict concerning slametan has been and is still going on even now in Trucuk. Since the puritan Islamic movement came to that village in the 1930s, signs of the cultural conflict have started to be felt, because the puritan Islamic group has forbidden the slametan tradition while the syncretic Islamic group regards slametan as part of its cultural system. It is recommended by the puritan group that the slametan tradition had better be God), forbidding people from practicing ziarah (e.g., visiting graves to pray, etc.), refusing invitations to attend slametan, telling people directly that they would not join or hold the slametan ritual, and begging people not to invite them to do the ritual. The most radical action was indulging in the destruction of keramat sites.

\subsection{Radical Action as Social Phenomenon}

Based on the several indications of cultural collision above, it is seen that the cultural values possessed by the puritan Islamic social group and those possessed by the syncretic one are different from each other or mutually contradictory. The puritan group tries to push away syncretic Islam due to consideration that mixed Islam should 
be purified to be in accordance with the holy book while the syncretists wish to preserve the cultural system that they already have. Compared to the puritanists, the syncretists have been earlier in arriving at the scene. Therefore, the puritanists' position is that of a penetration and pressure group to which the syncretists have responded with resistance so that tension between the two social groups is unavoidable.

What merits attention here concerning the tension is the radical (or "hard") action of the Muhammadiyah puritanists in conducting the penetration. It is a wonder that the radical action of the Muhammadiyah people has suddenly appeared in the rural community in Trucuk, Klaten. Activities of the Muhammadiyah movement researched by Peacock (1978), Nakamura (1983), Beck (1995), and Beatty (2001) do not exhibit indications of religious radicalism. On the contrary, the people concerned appear moderate in their treatment of the syncretic group.

Similarly, some research findings by Mulkhan (2000) and Bartholomew (2001) also indicate that the Muhammadiyah movement shows no radical attitude and action. In the case here, however, as previously mentioned, it is found in the field that the Muhammadiyah movement in Trucuk shows radical (or "hard") behavior. It is interesting that all of a sudden the Muhammadiyah movement indicates a pattern of radical action. That radical action of the Muhammadiyah movement is then considered not only a social phenomenon suddenly appearing in the Trucuk rural community but also a behavior with a subjective sense.

Syncretic members of society have made many complaints concerning such aforesaid action, stating that the puritanists act radically in all their forums of activity. Examples of the radical actions are forbidding the religious ways of the syncretic circles for the reason that such ways are considered contaminated with TBC (referring to takhayul, bid'ah, and khurofat), regarding ziarah at Ronggowarsito's grave as impure religious behavior, refusing to be invited to the slametan ritual, and causing the occurrence of invasions of keramat sites. All those are proof of radical action. Feeling their cultural rights torn by the puritan group, the syncretic members of society have been unable to take it; they have given resistance so that cultural collision has occurred. As said earlier, any radical action done by the Muhammadiyah puritanists to the syncretists has become a social phenomenon. The cause is that radical action has become a social regularity in the region of Trucuk, Klaten. Thus, what becomes the main point of the matter in the research concerned here is the behavior of Muhammadiyah people which is radical towards syncretic members of society so that it causes the occurrence of cultural collision.

\subsection{Puritanism Movement and Rationalization of Religion}

As written by Peacock, Muhammadiyah is referred to as puritan muslim (1978-b) or purifier of Islam teaching (1978-a) and as reformists (1979). Muhammadiyah, when claimed to be puritan Islam, is a religious movement toward purity of faith (or puritanism) always pushing far away the syncretic tradition loaded with TBC referring to takhayul, bid'ah, and khurofat. The consistency of the religious movement has made certain the tajdid (i.e., reformation) movement covering (1) the movement of purifying the comprehension, absorption, and application of the religious teaching whose source consists of the holy doctrines and (2) the modernization and reformation in the field of management and movement of congregations with originality of religious teaching still serving as basis.

The conception of Peacock (1978) concerning puritan teaching is based on Islamic reformation teaching, which could be said to resemble the Protestant Christian teaching. One should seek the truth oneself and it should not originate in excessive interpretation from the religious leader (ulama or priest, depending on the religion) but directly in the verses of the holy book concerned. The result to be achieved is the purification of religion back into that like the one brought by Muhammad SAW and Isa AS, as the case may be.

To get a picture of what a puritan is like, one should take the Muhammadiyah movement pictured like the religious reformation movement of the Calvinist Protestant Christian model (Kristiyanto, 2004, pp. 71-82), for a number of reasons (Sukidi, 2005, p. 5). First, both the Calvinist and the Muhammadiyah puritan muslim (or moslem) lean on holy teaching. The Calvinist has the Sola Scriptura doctrine of returning to the holy book (in this case, the Old and New Testaments) while Muhammadiyah wishes to return to the original source of Islam, namely, Al-Qur'an and As-Sunnah. Both Injil (or the Bible, the Christian holy book) and Al-Qur'an are set as the main source of authority and legitimation.

Second, in consequence of the "return to the original source of religious teaching", both the Calvinist and the Muhammadiyah puritan muslim stand or pray directly in the presence of God, not doing it through any intermediary (or wasilah). The Calvinist reforms the presence of an intermediary by minimizing the sacrament element and refusing the hierarchical church system. The Calvinist calls it the doctrine of Sola Fide, which means that only because of faith one is saved. Similarly, the Muhammadiyah puritan muslim views that there is 
no mediation in the relation between oneself and God. The puritan muslim stands alone and is responsible directly to God.

In addition, to show its puritan nature, Muhammadiyah is also called the reformation movement. The term reformation means that the basis is interpretation of the application and manifestation of Islamic teaching while still holding firmly to Al Qur'an and As-Sunnah. In this case, Peacock (1978-a) also states that Muhammadiyah is a puritan movement that makes the purifying or cleansing of Islamic teachings from syncretism its main focus. It all indicates that the puritanism movement is a religious rationalization movement (Hoffman, 2015).

\section{Research Methodology}

The subject of this research is involving the elites and activists of Muhammadiyah, the elite of politic parties, religion teachers, Nahdatul Ulama activists, mubaligh, puppeteer, mosque leaders, farmer, door-keeper of sacred places, visitors of grave, players and elders of reog, village chief, hamlet chief, village elders, etc. In short, this study subjects are informants from syncretism group (society tradition) and moderate and radical Islamic purification movement actors. This research is a kind of qualitative study which aims to understand about change process of farmer society from syncretism to pure Islam and the occurrence of cultural collision between cultural values brought by those who support Islamic purification movement and syncretism group in the community of Trucuk district, Klaten regency, Central Java provence, Indonesia. The cultural collision can be found out through reasons and explanations in the form of attitudes, views, and actions of both groups in the society. It can be regarding relationship character of the supporter of pure Islamic and syncretism culture, social institutions and social system employed, contextual aspects, and socio-politic situation which lead to the cultural collision occurrence and domination of Islamic purification movement.

In gaining comprehensive explanations about socio-cultural evidences in social groups of the supporter of pure Islamic and syncretism culture, ethnographic approach is employed. By the ethnographic approach (Spradley, 1997, p. 12), the researcher learns cultural evidences by representing view of life of this study subjects. The outline of theory employed to explain the social-culture phenomena in Muhamadiyah puritans' radicalism in the title of this dissertation are: (1) purification, (2) syncretism, (3) causing of the clash of Islamic culture is radicalism. The three phenomena above are to be variables and operational major which determine description of occurring on the clash of culture caused by radicalism of purist group to syncretist.

\section{Results}

\subsection{Change in the Farmer Community: from Syncretists into Puritanists}

The puritan community referred to here is the farmer community that has accepted Muhammadiyah (Note 5). In Trucuk, the Muhammadiyah community itself consists of around 11,000 members (Note 6). What is highly interesting of the data is that the number of farmer community members who are also radical-styled members of Muhammadiyah is half the overall number of members of the Muhammadiyah branch in Kecamatan Trucuk. It indicates that part of the farmer community that has all this time been participating in syncretic traditional activity has started to lose interest and to change into puritans and even radical puritans. As for the causes of the change in the rural farmer community of Trucuk from being syncretic into being puritan are as follows.

\subsubsection{Influence of Modernity in Education}

For a long time now, Klaten has been a prosperous region because its farmland promises fertility for rice planting. Therefore, many people regard Klaten as a rice barn capable of supplying various regions in the province of Central Java with enough rice. In Kenneth Orr's view, in consequence of the fertile place, in colonial days many Dutch-formed institutions were built with schools among them. Compared with other regions in Central Java, since Dutch occupation days Klaten has had the greatest number of educational institutions.

The great number of schools has enticed farmers' chidren's interest in acquiring knowledge. The region of Klaten is a region with noticable gaps among various social groups and competition in being able to have higher levels of schooling has been going on since even before Indonesia became an independent state in 1945. The aforesaid children have attended schools not only in Klaten but also in other regions like Solo and Yogyakarta, which have been noted also for their educational insitutions. Many farmers have been financially strong enough to pay for even the expenses of their chidren's schooling outside their home region. That has been all due to Klaten being a region with highly fertile farmland making its farming produce abundantly.

The rationalization of education in the region of Klaten has exerted influence on almost all tatanan tradisi, meaning that it has made farmers start to think of whether the tradition that they have been maintaining all along makes sense. After being able to rationalize about it, they have tried to change their way of life by means of eradicating tradition. In Weber's rationalization, it is mentioned, among others, that all traditional actions are 
considered unscientific or not reflecting rationality and would be replaced with rational actions (Waters, 1994).

The influence of rationalization through the lane of modernity manifested by acquiring school education is quite great. Many farmers' children attend school from the primary level to higher levels. As stated by Kenneth Orr, many schools of the primary level were opened on the initiative of local village people early in the days of independe. Even now, in Trucuk there are many schools, of which some are those public (or state-owned) in nature and some others are those owned by the Muhammadiyah foundation. In Trucuk, there are fifty-six kindergartens, forty primary schools, and three junior high schools. Weber's rationalization has been highly influential on the farmer community. There is the case of a young farmer and also seller of puthu who refuses to come whenever he is invited to attend slametan because he has once studied at a Muhammadiyah primary school.

The Muhammadiyah institution indeed takes the lane of modernity through prime business services in the form of, among others, schools, hospitals, and orphanages. In Klaten, Muhammadiyah schools range from kindergartens, primary schools, junior high schools, senior high schools, through to higher educational institutions (including universities). The Muhammadiyah schools in Trucuk consist of twenty-six kindergartens, seven primary schools, and, at junior high school level, one madrasah tsanawiyah. Muhammadiyah hospitals and clinics have also been erected, incuding a large clinic at the center of Kecamatan Trucuk and a small clinic whose place is shared wth the program of Pengajian Ahad Pagi, i.e., Sunday Morning Al-Quran Recitation. This lane of modernity is the bridge farmers pass to enter Muhammadiyah and become members or to move from being syncretic toward being puritan. As previously discussed, puritanism in religion is basically the same as rasionalization of religion.

\subsubsection{Influence of Reformation in Religion}

In Geertz's view (1960), the occurrence of social change in abangan-syncretic farmer community members becoming santri-puritan ones has caused syncretism and social integration to become increasingly eroded after being in existence for as long as fifty years. The change has been influenced by factors like population growth, urbanization, currency distribution, job differentiation, nationalism, Marxism, and religious reformation. The change has, in turn, influenced and caused the traditional ties of the farmer social structure to weaken. In particular, the social change resulting from the occurrence of the religious reformation claimed to be in the name of religious purification is the greatest power causing the impact of traditional ties fading in their role as residents' unifier.

Among the resulting cases of disintegration has been that of the split among farmer community members due to a change in course made by a part of them from being syncretic to being puritan. When the Muhammadiyah movement entered the Trucuk region in the 1930s, many farmers accepted the movement. The entrance of the movement into Trucuk in the 1930s occurred when the chairman of the central head officials of Muhammadiyah was H. Mas Mansyur. He has been the only chairman considered the most radical. And according to Trucuk Muhammadiyah community members, a radical Masyumi figure who was also a Muhammadiyah member, Singadimejo, once formally opened one of the Muhammadiyah organizations in Trucuk.

As stated by Redfield, originally the culture of the farmer community is autonomous in nature, meaning that it is an independent social culture, not requiring the support or influence of another system whose nature is complementary, reciprocal, and subordinate (Redfield, 1956). In other words, farmers' social culture is originally homogenous. However, whenever society members feel that their religious and moral knowledge is no longer complete enough for them, they attempt to complete it again by learning from the thoughts of such people from far away as great teachers, preachers, and philosophers. Likewise, when people from another culture come to a farmers' village, it would influence the farmer community members' thoughts in result of the social interaction between the visitors and the villagers. When two social groups meet face to face, a cultural transaction would occur. Mutual intercultural influence is often inevitable.

In the Trucuk case, the farmer community members have been split into two parts, namely, that consisting of those who have changed into puritanists and that consisting of those who have remained syncretists, proving that the presence of the Islamic puritanism movement that Muhammadiyah has brought with it has not always been able to eradicate the farmer community's syncretic tradition. In reality, those who have entered Muhammadiyah still faithfully attend slametan with the purpose of preserving the ancestral culture considered positive. As stated by Ngadimin, though he has become a member of an elite group in Muhammadiyah at the village level in Palar, his loyalty to tradition is evident in holding a feast celebrating a daughter's wedding and in still holding the wiwit ritual beginning a rice harvest though the prayers uttered are already Islamic ones. Elements referring to the mythical goddess called Dewi Sri usually paid homage to in the farmer community's ceremony or ritual right 
before a grand rice harvest have been eliminated and Islamic prayers have been used to replace them. He also prefers to retain the ceremony of bersih desa (literally meaning village cleansing) in Palar, agreeing more to keeping it being preserved than to having it eliminated. In the ceremony, there are a slametan ritual and a wayang performance. He adds that the wayang performance, which is a traditional dramatic puppet play, is highly positive in nature because it contains educational values. "Instead of spending the night gambling, it's better to do it watching wayang!" he remarks. Thus, a need to keep preserving syncretic tradition is still apparent along with the unceasing Islamic puritanism movement.

\subsubsection{Puritan Group's Domination of Mosques}

A chairman of a takmir, i.e., mosque managing board, with a Muhammadiyah background states that the mosque with its various rituals is the greatest social institution that should be overcome. The purpose is to make the dissemination of the Muhammadiyah teaching spread quickly in society. The victorious feeling of dominating the mosque would be attained when many Muhammadiyah members come to the place of worship. By means of this sort of domination, all the rituals and traditions of the community making use of the mosque (Kuat, 2015) could be controlled by the Muhammadiyah group. For that domination, the puritan group dares to quarrel with the syncretic group. The puritan group chooses to be bold and reckless by taking the radical way.

Efforts to rule the mosque is always made with the reasoning that when the mosque is already ruled by the traditionalists, then syncretism would again burgeon. The cause is that all syncretist religiosity in society is controlled by the traditionalists. Therefore, making kyais (religious leaders of traditional institutions) the enemy is one of the goals of the puritan group in view of their highly significant influence in rural society. All their fatwas, i.e., decrees, are obeyed by many society members. This way of blindly obeying tradition and the fatwas of kyais is called taqlid. In addition, kyais are turned into wasilahs (prayer intermediaries) by syncretic believers and members of society. Various forms of the slametan ritual held at houses or in keramat sites are led by a rois with a kyai or ulama background. In other words, any prayer could not be made by just anybody due to not possessing the right. The person possessing the right to make a prayer to be accepted by God is a kyai or ulama. After leading a prayer, a kyai receives cash payment called wajib. The puritanists put this way of making a kyai a prayer intermediary under reformation with the consideration that every person has the right to make a prayer without having to go through a kyai. This is similar to what Martin Luther did when making a serious protest against the papal institution in Rome in the $16^{\text {th }}$ century (Williamson, 1964). The protest was made against the papal institution for considering itself the party that could deliver the absolution of sins.

Such understanding of the puritan group's domination over mosques indicates that they wish for a return to the form of obedience to the basic principles of the religion. In addition, they demand a religious practice similar to the one taught and done by the Prophet. Certainly the domination has caused tension or conflict with the traditionalist group loaded with cultural-local aspects. The conflict experienced by the puritan and syncretic groups since the 1950s is, according to Geertz (1960), the most sharp and bitter conflict of Islamic people in Indonesia.

\subsubsection{Islamic Puritanism Movement as Radical Form of Struggle}

With radical actions, the puritanists have endeavored to fight for the truth of Islam by attempting to present all that is textual in the form of the holy doctrines in the holy book Al-Qur'an and As-Sunnah. This method of textual-natured religious comprehension and practice is in many things mutually contradictory with that of syncretic Islam. The radical action of putting in front holy doctrines has presented an appearance with a character admittedly not so moderate but, in the other hand, so highly spirited that it has caused syncretic Islam to feel pressed back from its position. It actually implies that the holy doctrines have been shown as teachings to be understood in an absolute way. In fact, the holy book is to be regarded as guide in life. Therefore, the puritanists regard syariat of Islam as a fixed price, i.e., unnegotiable (Barr, 1994).

On that basis, it could be pointed out that the puritan group's strength lies on its belief that its religious view, attitude, and action always based on Islamic law are the most right and on its consideration that another religious system like syncretism is not. Theologically, in each Islamic movement always settles a strength which is in the nature of a strong faith (or akidah) in the form of a world-view based on the source of Islamic teaching and the Prophet's life history which is special in nature, according to Weber's thesis (Schroeder, 1992). In that relation, a radical action to fight for syariat Islam becomes the spirit-giving fire to move the life power of the puritan Islamic group. In fact, the spirit-giving fire is always repeatedly mentioned, making the Islamic law able to take root cognitively, affectively, and psychomotorically. As said by an informant, Al-Qur'an should become a life guide. Islam is a struggle or a fight, otherwise it is not Islam, and from times in the past up to now Islam has always been fought for. 
What the puritan group has been fighting for, according to Kallen (1972), has been a form of religious radicalism which has three senses. First, it is a response to a current condition, usually in the form of an evaluation, rejection, or opposition. Second, it is an effort to replace the existing order with another (a new one). Third, it is characterized by the strength of the faith in the truth of the teaching it bears. When related to Kallen's opinion, the Islamic puritanism movement is a response to an ongoing condition, namely, that syncretism is still maintained in the rural area of Trucuk. The implied tradition is totally rejected by the puritan movement because it is considered soiling the faith. The radical struggle of the Islamic puritanism movement would even replace the order with a puritan one. It is caused by the strength of the faith in the truth of puritan Islam. The puritan group's radical struggle indicates that after it could eliminate completely the syncretic tradition, the group wishes to return the manifestation of pure Islam.

\subsection{Radical Action as Cause of the Islamic Cultural Collision}

\subsubsection{Considering the Slametan Tradition Not Dogmatic}

Palar is one of the villages in Kecamatan Trucuk which has become a basis of the syncretic traditional community. Though the Muhammadiyah movement has persistently had the puritan Islamic pengajian held, the syncretic community has kept continuing the tradition it has been getting along with for years. One participant of the pengajian held a ceremony including a slametan ritual to commemorate the $1000^{\text {th }}$ day after a parent of his died. It was held at night and attended by around seventy men. In the ceremony several ritual series were conducted and concluded with collective praying for ancestors' spirits.

After the end of the ritual series, the turn came for the program of a sermon of the pengajian to be delivered by a Muhammadiyah elite figure. In his sermon, he said that the slametan ritual tradition was forbidden by religion because there was no instruction concerning it in Al-Qur'an and Hadist. Therefore, he invited all the participants of the pengajian to immediately abandon the slametan ritual tradition. It means that being traditional was considered not being dogmatic (Chouiri, 1990). It was an example of a form of attack by the Muhammadiyah movement on the syncretists' (or abangans') ceremony concerning someone's death by explaining doctrines (Geertz, 1989, p. 189).

\subsubsection{Slametan Tradition Regarded as Form of Worshipping Other than God}

All the traditional activities in Palar such as slametan, ziarah, and the wayang kulit (or leather puppet) art have been considered musrik (or worshipping other than God). The puritan circles which have started to grow have been considered able to turn traditional activities into confusion. The Muhammadiyah tarjih (or judgment) institution has been even more so with its movement of going around like a giant thrashing all traditional activities in various rural areas. In its various pengajian, the tarjih institution has often made interpretations mentioning that there is no rule in the holy book concerning the slametan tradition. Such mention has been regarded by Palar people as a form of prohibiting their tradition or making it look bad.

The community in the village of Palar has felt divided into separate pieces after increasingly more members of the Muhammadiyah circles have begun abandoning such traditions. Certainly one or two Muhammadiyah people have been moderate still toward tradition by, for example, being willing to attend a slametan program. Radical Muhammadiyah people, however, have attacked traditional activities by means of prohibiting them, saying things negative about them, and branding them musrik. They have "attacked" people's traditions through the mosque forum by delivering lectures and sermons, pengajian from house to house, and social interaction.

The actions of the puritan group in attacking tradition has always had the pattern of makng prominent the source of religion, namely, the holy book. The tradition in the Palar village has been considered having no rule or deviating from Al-Qur'an and Hadist. That "terrorizing" statement has still been responded to by a supporter of syncretic tradition by saying that in the practice of a religion what is right or wrong is still determined by who is above (referring to God).

\subsubsection{Destruction of Tempat Keramat (Centers of Slametan)}

A cultural clash occurred when a gumuk (a mound of soil on the edge of a paddy field, shaped variously as half a ball, pyramide, or little hill. It is about a meter high and usually covered with bushes and grass) was vandalized by a group of puritan Islamic boys (Juergensmeyer, 2000). According to the belief of local people, inside the gumuk there was a mystical creature keeping guard over it so that the place was believed by rural people to be a keramat site. A gumuk is often visited by people from outside the village bringing with them offerings and tarub (i.e., ornament made of coconut tree leaves) with the purpose of getting a fortune. By abangan farmers, a gumuk located at a corner of a paddy field is intentionally left alone because it is considered able to guard the fertility of the field. 
The boys vandalized the gumuk previously mentioned by digging into it and making it as flat as the surrounding soil so that the gumuk really vanished. The destruction of the gumuk directly got a strong reaction from a farmer. He said to his friends, "Gumuk ora apa-apa kok dirusak, titeni wae mengko kualat" ('The gumuk did nothing wrong but it was destroyed; just wait and you will see something bad happening to them').

\subsubsection{Giving an Example of Not Holding a Slametan}

A collision of cultures took place when a member of the Islamic puritanism movement and his wife in the occasion of their first child's birth did not hold a slametan ritual. He said to the abangan people that the religion he embraced did not give instruction for a slametan ritual. In result, the abangan people protested against that cultural behavior of the man, who happened to be named Aryo Sucitro, because he denied the abangan people's culture that still applied. A neighbor even had a chance to call him names by saying, "Kowe kuwi dudu manungsa" ('You are not human'). What the neighbor meant was that the customary way for a human being to be born was with slametan. If one was born with no slametan, one would be considered like an animal.

But the puritan man remained kukuh (constructed by society members as strict attitude in practicing religion), or firm, in attitude, meaning that he kept refusing to hold the slametan ritual. He even often advised abangan people to abandon the slametan ritual. In result, an assistant of the caretaker of a keramat tree given the name mBah Bero got angry and would hit him but the puritan responded to him coolly and smilingly.

In the reconstruction made by Geertz (1989), someone who holds a slametan ritual is not regarded as an animal. Someone holding slametan in the fasting month is not regarded as kafir (an infidel or unbeliever). Someone carrying a tray containing various food to the slametan place of bersih desa would not be regarded subversive. Geertz wishes to emphasize that all Javanese people without exception should participate in all kinds of slametan The reason is that someone who does not hold slametan would be considered different from others.

\subsubsection{Puritan Group's Understanding of Radical Action}

The puritanists' radical action to avoid syncretic tradition has not appeared to go only halfway; on the contrary, it has been done secara habis-habisan. In result, syncretic people have felt that the tradition yang telah ditekuninya and has become part of their life spirit would be destroyed by the puritan circles. In facing the puritan people, syncretic people have complained as follows. Mr. Mukhlas stated, "The tradition has become established and lived since a long time ago in society but now it is diobrah-obrah (digempur) by the puritan group." Mbah Narso, a caretaker of a keramat tomb, felt confused because almost every day he received a smash (pressure). Mr. Muji, a farmer, asked with a hopeless tone, "Kok nganyar-nganyari gawe tatanan?" ("Why make new rules in religion?') while Mr. Ngadi, a rois, threatened to beat up puritan people (Ostertag, 2014).

Meanwhile, a puritan, in spreading Islamic teaching, should be textual though clashing with the syncretic group. It is in line with Peacock (1986), who says that the Muhamadiyah movement is of purification from the influence of the syncretism culture and a return to a firm hold to the teaching of Al-Qur'an. The group principle of amar makruf nahi munkar ('inviting goodness and shunning evil) is practiced with firmness and courage. Included in the mission is a desire to bring back the syariat Islam referring to the purity of holy text and staying away from syncretic Islam based on TBC (i.e., takhayul, bid'ah, khurofat) considered "dirt". To lead to the pure teaching, some cleansing should be done to remove the "dirt". As impact of the puritan group's firmness and courage, the syncretic group's position has become shifted aside. Sensing its position having been pushed to the edge, the syncretic group has attempted to resist by various means such as ridiculing, ostracizing, cursing, reprimanding, and threathening to hit puritan people. In that way, there has been a cultural collision, which has been a collision between puritan Islamic values and syncretic ones.

On the face of the cultural collision, the puritanists have not been daunted at all. Any risk should be taken. The reason is that the cultural clash is made accountable by religion (Huntington, 1993); on the average the puritanists have explained by referring to text interpreted by referring to life stories of the Prophet such as the one telling that even the Prophet, when inviting Arab people to good ways, was assaulted with dirt, spat at, and about to be killed. This text has always been complemented with the next telling people to tell the truth though it felt bitter. The latter text has the implication that the puritanists should dare to tell the real Islamic teaching in accordance with the holy doctrines in Al-Qur'an and As-Sunnah in spite of the risks they have to take in doing so.

When Martin Luther made a protest against the papal institution of the Roman Catholic church in the $16^{\text {th }}$ century, the risks he took were not small. His courage in bringing news of the truth of the religion to the public made him the object of the cardinals' condemnation and ostracism; the Pope even ordered the king of Germany to kill him (Williamson, 1964). Something similar was experienced by Imam Hanbali in making purification in 
religion. He was arrested and imprisoned by the Abassiyah dynasty. Throughout his imprisonment, he received the cruel treatment of being beaten and flogged (Fas-Kal, 1993). His follower who was also a famous figure in Islamic revivalism, Ibnu Taimiyah, was also arrested and imprisoned.

Radical actions have been done by the Muhammadiyah puritan group with awareness of the intention of practicing the pure Islam as practiced by the Prophet Muhammad and his companions in the $7^{\text {th }}$ century as the initial Islamic generation in the Middle East. The actions have been done in view of the syncretism burgeoning in the rural region of Trucuk and centering on keramat sites like graves, mounds, large trees, springs, paddy fields, and mosques. With the radical actions, they would like to return the Islam religion to its pure form by using the slogans as follows: return to holy texts (return to Al-Qur'an and Hadist), revive the true Islamic teaching, akidah Islam is considered a fixed price, i.e., unnegotiable, and do not be taqlid (blindly obedient) to traditional ulamas. In returning to holy texts, the case is the same as that of a slogan of religious protestantism glorified by Calvinists: Sola Scriptura ('return to the holy book').

Radical actions in relation with efforts to return to the holy book have given rise to a religious perception and attitude believed to be the most right. In puritanists, the perception and attitude have given birth to the feeling that the puritan Islam is evaluated as the religion which is the most true, perfect, and able to save themselves and to the consideration that other religions, especially those syncretic in style, are evaluated as already contaminated or mixed up with other elements. In consequence, syncretic beliefs are regarded as misleading beliefs. Because they have been considered misleading, through radical actions the puritanists' hearts have been aroused to want to decrease syncretic religious practice by destroying keramat sites. The radical action could be viewed as a form of a reproduction of the Wahabi movement in the Middle East as an Islamic revivalism movement radically done. The revivalism movement was an effort to bring back to life the faith of the Prophet's era and cleanse it from foreign elements as well as to make resistance and reformation until finally to withdraw from a life considered disappointing or, in Ka'bah's view, it was a strong desire to imitate what was authentic (Ka'bah, 1984).

\section{Conclusion}

The change of the farmer community from being abangan to being santri has been influenced by (1) modernity of education and (2) reformation of religion. In relation to that, first, the rationalization of education in the region of Trucuk has influenced almost all the order of tradition. It means that with the occurrence of the rationalization of education, members of the farmer community have started to think of whether the tradition they have maintained all this time has been rational. After being able to retionalize, they have tried to change their lives by means of eliminating tradition. In Weber's rationalization, it is mentioned, among others, that all traditional actions are not considered scientific or reflecting rationality. All traditional actions would be replaced with rational actions (Waters, 1994).

Second, the social change resulting from the occurrence of religious reformation in the name of purification in religion has been the greatest power for them. An impact of the social change has been the fading of traditional ties as residents' unifiers. It has already been seen in the shadows of a widening gap with syncretic Islamic people. That is the matter that has been presented to two contrasting social groups, namely, the puritan and syncretic groups. According to Geertz, two contrasting social groups are represented by the santri and abangan groups. The santri group stresses the religious practice of the international teaching from Muhammad while the abangan group stresses the religious practice of inherited tradition (Geertz, 1960).

The radical actions done by the Muhammadiyah group have caused a collision of cultures. They have been aware of doing radical actions for the purpose of revealing the pure Islamic teaching. The presence of a radical-puritan Islamic movement pioneered by the Muhammadiyah group to fight for the formalization of Islamic law has been a new social phenomenon in the development of Islamic movement in rural regions. The radical actions in relation with holy doctrines have given rise to a religious perception and attitude regarded by them as the most right. The perception and attitude have given birth to their feeling that the puritan Islam is judged as the religion which is the most right, perfect, and able to save them and they have considered other religions, with the ones whose style is syncretic in particular, evaluated as religious types already contaminated or mixed up with other elements.

Using the holy texts as basis, the puritan group has tried to fight for syariat Islam radically though cultural collisions with the syncretic group have occurred. Islamic law has become the idealization to fight for strictly and continuously without cease. Fighting for Islamic law strictly and continuously is a radical action (Kallen, 1972); it is an effort to replace the ongoing order with another order, which means, in this case, replacing the syncretic order with a puritan one. Thus, the assault on syncretic tradition by the puritan society members has gone on continuously. In the eyes of the puritan group, the syncretic world in all its various forms should exist no 
more.

\section{References}

Barr, J. (1994). Fundamentalism. Jakarta, Indonesia: BPK Gunung Mulia.

Beatty, A. (1999). Varieties of Javanese Religion, An Anthropological Account. Cambridge: Cambridge University Press. http://dx.doi.org/10.1017/CBO9780511612497

Beck, H. (1995). Islamic Purity at Odds With Javanese Identity: The Muhammadiyah and the Celebration of the Garebeg Maulud Ritual in Yogyakarta. In J. Plavoet \& K. V. D. Toorn (Eds.). Pluralism and Identity, studies in Ritual Behavior. Leiden, New york, Koln: EJ. Brill.

Choueiri, Y. M. (1990). Islamic Fundamentalism. London: Pinter Publishers. Retrieved from http://www.muslim philosophy.com/ip/rep/H007.htm

Fas-Kal. (1993). Ensiklopedi Islam 2. Jakarta: PT Ichtiar van Hoeve

Feillard, A. (1999). NU vis-à-vis Negara: Pencarian Isi, Bentuk dan Makna. Yogyakarta, Indonesia: Lkis.

Geertz, C. (1960). The Religion of Java. London: The Free Press of Glencoe.

Geertz, C. (1973). The Interpretation of Culture. New York: Basic Books, Inc.

Hoffman, V. J. (2015). Mysticism, Rationalism and Puritanism in Modern Omani Ibādism (18th-Early 20th Century). The Muslim World, 105(2), 251-265. http://dx.doi.org/10.1111/muwo.12091

Huntington, S. P. (1993). The Clash Civilization. Foreign Affair, $72(3), \quad 22-49$. http://dx.doi.org/10.2307/20045621

Juergensmeyer, M. (2000). Terror in the Mind God: The Global Rise of Religious Violence. Berkeley, Los Angeles, London: University of California Press. Retrieved from http://www.jstor.org/stable/10.1525/j. ctt4cgfbx

Ka’bah, R. (1984). Islam and Fundamentalism. Jakarta, Indonesia: Pustaka Panjimas.

Kristiyanto, E. (2004). Reformasi dari Dalam: Sejarah Gereja Jaman Modern. Yogyakarta, Indonesia: Kanisius.

Kuat, I., Zhangali, B., Nazira, A., Serik, K., \& Nurtas, A. (2015). Islamic Obligation in Kazakh Customary Law (For Example, the Institution of Family and Marriage). Asian Social Science, 11(26), 121-128. http://ccsenet.org/journal/index.php/ass/article/view/50420/28386

Nakamura, M. (1983). The Crescent Arises over the Banyan Tree. Yogyakarta: Gadjah Mada University Press.

Orr, K. (1991). Schooling and Village Politics in Central Java in the time turbulence. In R. Cribb (Ed.), The Indonsian Killing 1965-1966: Studies from Jawa and Bali. Clayton, Victoria: Centre of Southeast Asia Studies Monash University.

Ostertag, S. F. (2014). Becoming Pure: The Civil Sphere, Media Practices and Constructing Civil Purification. Cultural Sociology Journal, 8(1), 45-62. http://dx.doi.org/10.1177/1749975513485566

Peacock, J. L. (1978). Muslim Puritan: Reformist Psychology in South East Asia. Berkeley: University of California Press.

Redfield, R. (1956). Peasant Society and Culture: An Anthropological Approach to Cilivization. Chicago: University of Chicago Press.

Schroeder, R. (1992). Max Weber and the sociology of culture. London: Sage. Retrieved from http://www.amazon.ca/Weber-Sociology-Culture-Ralph-Schroeder/dp/0803985509

Sukidi. (2005). Muslim Protestant Puritan ethic: As Muhammadiyah Islamic Reformation Protestant Model. Kompas, 1 Juni.

Waters, M. (1994). Modern Sociological Theory. London: Sage Publication.

Wiliamson, F. E. (1964). Martin Luther Searching for the Truth. Jakarta, Indonesia: Badan Penerbit Kristen.

Woodward, M. R. (1988). Islam in Java: Normative Pietyand Mysticism in the Sultanate of Yogyakarta. An Arbor: UMI. Retrieved from http://www.jstor.org/stable/1062723

\section{Notes}

Note 1. Abangan refers to people of Java, Indonesia, whose religion is Islam, according to their ID cards, but 
they do not pray five times a day as required. Abangan people hold such a ceremony as slametan. They belong to the syncretic circles.

Note 2. Santri refers to people of Java, Indonesia, whose religion is Islam, as mentioned in their ID cards, and they accordingly pray five times a day as required and practice the syariat (laws) of Islam. They belong to the puritan circles.

Note 3. The research concerned here was conducted in the rural region of Kecamatan Trucuk, Kabupaten Klaten, Propinsi Jawa Tengah, Indonesia.

Note 4. Muhammadiyah is the greatest Islamic socio-religious organization in Indonesia. Its principle is basing itself purely on Al-Quran, the holy book of Islam, and the Hadists, collections of reported sayings of the Prophet. Its followers eradicate TBC (as abbreviation of takhayul, bid'ah, khurofat). Takhayul is belief in something considered existent while actually it is not. Bid'ah is a ritual of worship practiced not according to examples already provided; it includes additions to and subtractions from what is already decreed, without basis from Al Qur'an and the Prophet's sayings. Khurofat is irrational teaching. The Muhammadiyah community is also called a puritan community.

Note 5. Report by Chairman of PWM, Jawa Tengah, in the course of Muswil in Purwokerto, April 2006, mentions that the greatest number of the Muhammadiyah movement followers in Propinsi Jawa Tengah come from Kabupaten Klaten. It is even pointed out to be greatest in Indonesia and in the whole world, in view of the fact that the Muhammadiyah organization already has branches in Singapore, Malaysia, Thailand, Pakistan, and Egypt.

Note 6. PRMs in Kecamatan Trucuk are twenty-four in number, making the area a rural area and simultaneously an interior area in one kecamatan with he greatest number of PRMs in Klaten, Jawa Tengah, Indonesia, and even in the world.

\section{Copyrights}

Copyright for this article is retained by the author(s), with first publication rights granted to the journal.

This is an open-access article distributed under the terms and conditions of the Creative Commons Attribution license (http://creativecommons.org/licenses/by/3.0/). 